\title{
Influence of stored aqueous ceftriaxone solutions on colony formation by neutrophil and macrophage precursor cells
}

\author{
M. Kisslinga, P. Keller ${ }^{b}$ and C. Nissen ${ }^{c}$ \\ 'Pharma Clinical Research, F. Hoffman-La Roche \& Co., Ltd. CH-4002 Basle, \\ Switzerland; 'Biological-Pharmaceutical Research Department, F. Hoffmann-La Roche \\ \& Co., Ltd. CH-4002 Basle, Switzerland; 'Department of Haematology of the \\ University Clinic of Basle, CH-4031 Basle, Switzerland

\begin{abstract}
Aqueous solutions of ceftriaxone in concentrations similar to those achieved in man and stored at temperatures of $4^{\circ} \mathrm{C}, 22^{\circ} \mathrm{C}$ and $37^{\circ} \mathrm{C}$ for up to four weeks were tested in methylcellulose cultures of normal bone marrow from ten donors.

No significant differences were detected between the colony formation by neutrophil and macrophage precursors in control cultures and in cultures containing stored ceftriaxone.

It is concluded that aqueous ceftriaxone solutions stored for up to four weeks at temperatures up to $37^{\circ} \mathrm{C}$ are not altered to such an extent that they adversely affect colony formation by bone marrow progenitor cells from healthy donors.
\end{abstract}

\section{Introduction}

Penicillin and cephalosporin derivatives have been reported to induce neutropenia and it has been claimed that degradation products of these antibiotics are responsible for this side effect (Müller et al., 1983).

We therefore studied the influence of stored ceftriaxone, a semi-synthetic cephalosporin, on colony formation of myeloid precursor cells in vitro, using the methylcellulose assay.

\section{Ceftriaxone solutions}

\section{Materials and methods}

A sterile ceftriaxone (Rocephin) solution was prepared at a concentration of $1 \mathrm{mg} / \mathrm{ml}$ in redistilled water and stored for up to four weeks at $4^{\circ} \mathrm{C}$, at room temperature (approx. $22^{\circ} \mathrm{C}$ ) and at $37^{\circ} \mathrm{C}$. Aliquots of this solution were appropriately diluted and tested on bone marrow myeloid precursor cells as described below.

\section{Bone marrow cultures}

Cryopreserved nucleated bone marrow cells $10^{5} / \mathrm{ml}$, with approximately $90 \%$ viability as determined by trypan-blue exclusion, obtained from ten bone marrow transplantation donors, were incubated in $5 \% \mathrm{CO}_{2}$ at $37^{\circ} \mathrm{C}$ in a humid atmosphere in Iscove's modified Dulbecco's medium (Gibco, E 096550). This medium 


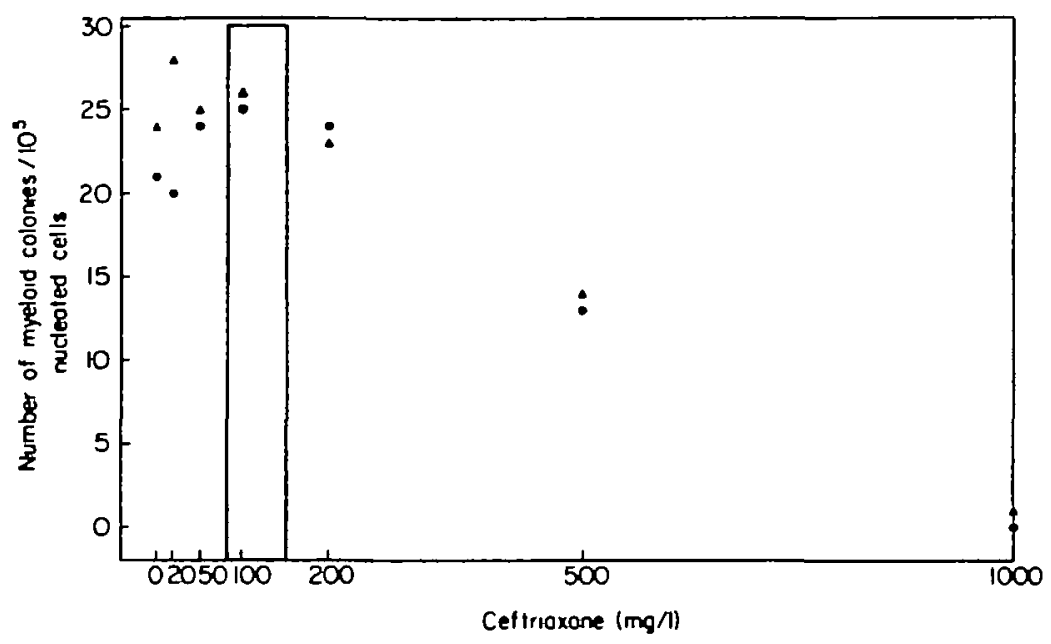

Figure 1. Effect of freshly prepared ceftriaxone on colony formation by neutrophil and macrophage precursors. $\triangle$, Result of experiment 1 (two bone marrow samples); $O$, result of experiment 2 (two bone marrow samples). Stippled = therapeutic plasma ceftriaxone concentration (peak plasma concentration obtained $30 \mathrm{~min}$ after iv infusion of 0.5 and $1 \mathrm{~g}$ of ceftriaxone).

contained $0.8 \%$ methylcellulose, $16 \%$ fetal calf serum (Gibco), $1 \%$ de-ionized and delipidated bovine serum albumin, $360 \mathrm{mg} / \mathrm{l}$ of human transferrin (Otre) and $16 \% \mathrm{v} / \mathrm{v}$ human PHA-induced leucocyte conditioned medium (CM). After 14 days, colonies formed by myeloid precursor cells were counted and differentiated with the aid of an inverted microscope.

\section{Evaluation and statistics}

Results are expressed as arithmetical mean and standard error of the mean (S.E.M.). For statistical evaluation the non-parametric two-way analysis of variance according to Friedmann (Siegel, 1956) was used.

\section{Results}

As shown in Figure 1, freshly prepared ceftriaxone did not inhibit proliferation of myeloid precursor cells in concentrations up to $200 \mathrm{mg} / \mathrm{l}$, while colony growth was reduced to about $50 \%$ by $500 \mathrm{mg} / \mathrm{l}$ and totally abolished by $1000 \mathrm{mg} / 1$ of ceftriaxone. Furthermore, no colony growth was observed in cultures containing no ceftriaxone and no $\mathrm{CM}$.

Based on these results, concentrations of $100 \mathrm{mg} / \mathrm{l}$ of ceftriaxone were added to the cultures in the subsequent storage experiments. Neither storage at room temperature $\left(22^{\circ} \mathrm{C}\right)$, nor at $4^{\circ} \mathrm{C}$ or at $37^{\circ} \mathrm{C}$ for up to $96 \mathrm{~h}$ revealed any adverse effect on myeloid colony growth (Table I), even though a slight yellowish colour was observed in aqueous ceftriaxone solutions kept for $24 \mathrm{~h}$ at $37^{\circ} \mathrm{C}$. During $24 \mathrm{~h}$, degradation of ceftriaxone in solution amounted to $1-3 \%$ at $22^{\circ} \mathrm{C}$ and up to $9 \%$ at $37^{\circ} \mathrm{C}$. Correspondingly, $1 \cdot 1-2 \cdot 1 \%$ and $4 \cdot 3 \%$, respectively, of decomposed active substance was formed at these storage temperatures. 
Table I. Comparison between colony formation by neutrophil and macrophage precursors in control cultures and in cultures containing aqueous ceftriaxone solutions stored at various temperatures for up to $96 \mathrm{~h}$

\begin{tabular}{|c|c|c|c|c|c|}
\hline Assay & & $\begin{array}{c}\text { Number } \\
\text { of } \\
\text { donors }\end{array}$ & $\begin{array}{l}\text { Number of myeloid } \\
\text { colonies (cfu-c) } / 10^{5} \\
\text { nucleated cells }\end{array}$ & S.E.M. & $\begin{array}{c}\text { Computed } \alpha \\
\text { (preassigned } \\
\alpha=0.050 \text { ) }\end{array}$ \\
\hline $\begin{array}{l}\text { No ceftriaxone } \\
+ \text { ceftriaxone } \\
+ \text { ceftriaxone } \\
+ \text { ceftriaxone }\end{array}$ & $\begin{array}{l}\left(0.5 \mathrm{~h} / 22^{\circ} \mathrm{C}\right) \\
\left(48 \mathrm{~h} / 22^{\circ} \mathrm{C}\right) \\
\left(96 \mathrm{~h} / 22^{\circ} \mathrm{C}\right)\end{array}$ & $\begin{array}{r}10 \\
10 \\
10 \\
9\end{array}$ & $\begin{array}{l}33 \cdot 2 \\
34 \cdot 4 \\
34 \cdot 1 \\
34 \cdot 6\end{array}$ & $\begin{array}{l}3 \cdot 02 \\
2 \cdot 13 \\
2 \cdot 12 \\
2 \cdot 72\end{array}$ & $0.972=$ n.s. \\
\hline $\begin{array}{r}\text { No ceftriaxone } \\
+ \text { ceftriaxone } \\
\text { + ceftriaxone } \\
\text { + ceftriaxone }\end{array}$ & $\begin{array}{l}\left(0.5 \mathrm{~h} / 4^{\circ} \mathrm{C}\right) \\
\left(48 \mathrm{~h} / 4^{\circ} \mathrm{C}\right) \\
\left(96 \mathrm{~h} / 4^{\circ} \mathrm{C}\right)\end{array}$ & $\begin{array}{r}10 \\
10 \\
10 \\
9\end{array}$ & $\begin{array}{l}35 \cdot 3 \\
33 \cdot 7 \\
34 \cdot 7 \\
34 \cdot 8\end{array}$ & $\begin{array}{l}2 \cdot 83 \\
2 \cdot 42 \\
2 \cdot 69 \\
2 \cdot 35\end{array}$ & $0.463=$ n.s. \\
\hline $\begin{array}{l}\text { No ceftriaxone } \\
+ \text { ceftriaxone } \\
+ \text { ceftriaxone } \\
+ \text { ceftriaxone }\end{array}$ & $\begin{array}{l}\left(0.5 \mathrm{~h} / 37^{\circ} \mathrm{C}\right) \\
\left(48 \mathrm{~h} / 37^{\circ} \mathrm{C}\right) \\
\left(96 \mathrm{~h} / 37^{\circ} \mathrm{C}\right)\end{array}$ & $\begin{array}{r}10 \\
10 \\
10 \\
9\end{array}$ & $\begin{array}{l}34 \cdot 3 \\
35 \cdot 8 \\
33 \cdot 8 \\
34 \cdot 8\end{array}$ & $\begin{array}{l}2 \cdot 56 \\
2 \cdot 34 \\
2 \cdot 33 \\
2 \cdot 21\end{array}$ & $0.339=$ n.s. \\
\hline
\end{tabular}

n.s., No significant differences between colony counts resulting from different storage conditions and those of the controls.

In order to detect possible effects of prolonged storage, aqueous ceftriaxone solutions kept for two, three and four weeks at the three temperature levels were additionally tested on bone marrow cultures from a small number of donors. Again, myeloid colony growth remained unaffected by the stored ceftriaxone and the results obtained were in good agreement with those of the control cultures. After aqueous ceftriaxone solutions had been stored for four weeks and then tested on bone marrow cultures from two donors, the following numbers of myeloid colonies $/ 10^{5}$ nucleated cells were obtained (mean \pm S.E.M.): controls $=39 \cdot 0 \pm 0$, stored ceftriaxone $\left(22^{\circ} \mathrm{C}\right)=38.0 \pm 2 \cdot 0 ; \quad$ controls $=39.0 \pm 6.0, \quad$ stored ceftriaxone $\left(4^{\circ} \mathrm{C}\right)=38.5 \pm 4.5 ;$ controls $=40 \cdot 0 \pm 1 \cdot 0$, stored ceftriaxone $\left.\left(37^{\circ} \mathrm{C}\right)=39 \cdot 5 \pm 0 \cdot 5\right)$.

\section{Discussion}

Neutropenia has occasionally been reported following treatment with high doses of ceftriaxone, but as yet no proof of a causal relationship between the adverse reaction and the medication has been produced. The incidence of this side effect during treatment with ceftriaxone is extremely low and amounts to $0.35-0.54 \%$ of the patients according to literature reviews covering some 1347 publications and presentations and up to 8565 patients (Havas, Fernex \& Kissling, 1983; Fernex, M., Havas, L. \& Kissling, M., unpublished results). Comparative trials with 4100 patients given ceftriaxone and 4238 patients given standard antibiotic therapy revealed identical incidences of neutropenia in both groups.

However, in view of the potential therapeutic advantage of parenteral out-patient therapy in rural areas using pre-prepared ceftriaxone solutions, proof was desired that stored ceftriaxone solutions do not alter to such an extent that they adversely affect 
colony formation by myeloid bone marrow precursor cells and thus induce neutropenia.

The use of Iscove's seme-solid culture method was the method of choice as it has been successfully applied by other authors to investigate similar problems (Negishi \& Young, 1985). Even though our criteria in the study design were very strict, the added ceftriaxone solutions did not interfere with colony growth by myeloid bone marrow precursor cells from healthy donors.

This result is comparable to the findings reported by Osterwalder et al. (1986), who investigated whether or not therapy with cephalosporin alone or combined with other $\beta$-lactam antibiotics (even in doses in excess of $100 \mathrm{~g}$ in ten days or more) inhibited myelopoiesis in vivo in patients with allogeneic bone marrow transplants. These authors stated that no inhibitory influence of cephalosporin or combinations thereof with other $\beta$-lactam antibiotics on myelopoiesis was detectable in patients with severe aplastic anaemia and who had undergone bone marrow transplantation.

\section{References}

Havas, L., Fernex, M. \& Kissling, M. (1983). Literature survey on the clinical efficacy and tolerance of ceftriaxone: an analysis of 3961 cases. In Proceedings on Progress in Therapy of Bacterial Infections. A New Cephalosporin: Ceftriaxone, Asia Pacific Congress Series No. 19, pp. 130-45. Excerpta Medica, Amsterdam.

Müller, M., Neftel, K., Wälti, M., Hauser, S., Erni, J. \& Arrenbrecht, S. (1983). Semisynthetische Penicilline und Cephalosporine hemmen die In-vitro-Myelopoiese dosisabhängig. Schweizerische Medizinische Wochenschrift 113, 1471-3.

Negishi, M. \& Young, C. (1985). Effects of ofloxacin on the haemopoietic stem cells and comparison with other antimicrobial agents. In Recent Advances in Chemotherapy, Antimicrobial Section (Ishigami, J., Ed.), pp. 861-2. University of Tokyo Press.

Osterwalder, B., Haberthür, C., Gratwohl, A. \& Speck, B. (1986). Können BetalactamAntibiotika (BLA) die Myelopoiese in vivo hemmen? Eine Studie bei 115 Patienten mit allogener Knochenmarktransplantation (KMT). Schweizerische Medizinische Wochenschrift 116, Suppl. 20, 26.

Siegel, S. (1956). The Friedmann two-way analysis of variance. In Nonparametric Statistics for the Behavioral Sciences, Siegel, S., Ed.), pp. 166-73. McGraw-Hill, New York.

(Manuscript accepted 12 January 1987) 